\title{
A Regional Cultural Comparison of Medical Tourism Preference in China
}

\author{
Jun Zhang*
}

Received: June 28, 2018. Revised: July 14, 2018. Accepted: August 15, 2018.

\begin{abstract}
Purpose - The effect of regional culture has been acknowledged for decades. However, very little research takes it as an important issue in the medical tourism service decision process. This study focuses on regional culture to identify customers' preference for medical tourism in the international environment. It is proposed that regional culture may work as an critical moderator in the international medical tourism destination choice process. Especially, the destination attributes may vary according to regional culture.

Research design, data, and methodology - By the questionnaire survey, the sample is collected from 2,041 potential Chinese residents in different regions of China. Regression analysis is constructed to test the effect of regional culture on Chinese customers' destination preference.

Results - Results imply that regional culture plays a critical moderating role in the destination choice process. Results also indicate that destination attributes including medicine and travel characteristics are the important predictors of destination preference.

Conclusions - This study provides the fundamental base to use regional culture as a descriptive variable for segmentation when establishing an effective marketing strategy. Furthermore, this research suggests that different strategies relied on destination attributes should be made to attract more Chinese customers for the development of medical tourism industry.
\end{abstract}

Keywords: Regional Culture, Destination Attributes, Preference of Medical Tourism.

JEL Classifications: I15, M31, Z32.

\section{Introduction}

Culture has been documented as an important factor influencing behavior and decision-making process over the past decades (de Mooij \& Hofstede, 2011). In general, it reflects the collective programming of the mind which distinguishes the members of one group or category of people from another (Hofstede, 1980, 1993). Since then, increasing numbers of cross-cultural management researchers have made efforts to estimate the culture effect across different nations. Some of the existing studies explain regional cultural differences which are relevant to organizational management (e.g., Bird \& Mendenhall, 2016; Dong \& Liu, 2010; Tse, Lee, Vertinsky, \& Wehrung, 1988), while others attempt to investigate cross-cultural impact on customers' buying patterns, motives, and decision-making

* Assistant Professor, Department of Global Business, Konkuk University, Korea. Tel: +82-2-450-4048, E-mail: zhangjun@konkuk.ac.kr process (e.g., You, O'leary, Morrison, \& Hong, 2000; Yu \& Ko, 2012; Zhang, Seo, \& Lee, 2013).

Despite these studies, the effect of cross-culture remains unclear. It is because a large and complex national culture, such as the European or the Chinese one, may have regional differences. Evidences can be found in the previous research. Clifton (2011) observed three European regions of Gyor, Styria, and Wales to explore the regional culture effects on the market place. Macnab, Worthley, and Jenner (2010) found significant regional differences between Hawaii and Florida of the United States. However, these studies emphasize a regional cultural perspective in the market of Western countries. Very little takes the regional cultural phenomenon of Asian nations as important issues, although scholars have payed attention to verify the influence of cross-culture in China market since 1990s. Therefore, this study proposes that regional culture may be a critical factor that influences customers' preference in the decision-making process. 
In this study, the China market is selected as the target for several reasons. First, China is a country with rich heritage. The culture in different regions, such as the North, the Northeast, the East, and the South Central China, may lead customers from these regions to construct different beliefs or norms, and then make different decisions (Ge, 2012; Qian, Razzaque, \& Keng, 2007). Second, the rapid economic development and aging problems have made Chinese customers go abroad with various motives such as traveling for the more and better medical services (Zhang et al., 2013). The emerging growth of medical tourism has made China as the great and attractive market around the world. Scholars and managers from different countries prefer to concentrate on this market to investigate customers' purchasing behavior, because the consumption power in China has had and certainly will continue to have the significant effect on world economy. Third, the previous research has focused on medical quality and cost to estimate the customers' behavior of medical tourism (e.g., Connell, 2013; Turner, 2010; Zhang et al., 2013), little emphasized the importance of culture. However, the problem is that the culture has changed in the last decades due to the economical and political environment changes (Ge, 2012). A new understanding of the Chinese culture is necessary. Thus the study of the Chinese regional differential impact on medical tourism destination preference may be timely and revealing.

For the purposes of this study, it proposes that the culturally based Chinese regions would lead to differences in health care service decision-making. A regional cultural perspective will be established to analyze the differences in the potential customers among the different regions in China. Given the background, this study has two main specific objectives. First, this study is to gain a regional cultural understanding of customers' preference for medical tourism in the China market. Second, within the effects of regional culture, the potential selective factors of medical tourism will be analyzed to see how the destination attributes affect preference and participation in medical tourism services. The findings of this study support the use of regional culture as an important marketing tool for medical tourism industry development.

\section{Literature Review}

\subsection{Medical tourism in China}

Medical tourism is defined as people traveling across borders in search of medical care for healing and relaxation with affordable cost (Connell, 2013; Goodrich \& Goodrich, 1987; Zhang \& Lee, 2017; Zhang et al., 2013). Although its beginning can be tracked back into the seventeenth century when wealthy people from Europe going abroad for spar and springs (Lee, Han, \& Lockyer, 2012; Yu, Lee, \& Noh,
2011), in China, it becomes popular in the current years.

The development of China's medical tourism can be classified into three stages (China Business Industry Research Institute of $\mathrm{ASKCl}, 2016)$. The first trial stage is from 2000 to 2010 . In this stage, only a few wealthy customers have the economic abilities to seek the medical facilities with higher quality abroad. The demands and supplies of medical tourism cannot be distinguished clearly. The next stage is from 2011 to 2014. In this initial stage, the target in China has expanded to the middle-rich class due to the rapid economic development. The suppliers around the world thus focus on this potential market and attempt to provide service with higher quality and lower price for financial profit. The development stage is from 2014 until the present. In the recent stage, the Internet is naturally developed in China, which has greatly changed customers' life. Customers therefore can participate international medical tourism activities equally through Internet. As reported in the China statistics in 2016, there were 122 million Chinese travelers going abroad for healing. As compared to 2015, it has increased 4.3\% (China Tourism Academy, 2017). UNWTO predicted that in the near future five years, it would achieve 700 million (Wu \& Liang, 2017; Zhang \& Lee, 2018).

The rapid growth of Chinese outbound market has attracted practitioners and researchers to explore the important factors that may affect customers' preference of the specific service. A large body of existing studies focus on destination attributes such as higher medical quality and attractive traveling products to explain customers' behavior (e.g., Connell, 2013; Turner, 2010). Until now, few studies explain the cultural effect of different regions in China, even though its importance cannot be ignored. Therefore, this research proposes that the regional differences in Chinese culture, discussed in the following section, should be a critical factor for Chinese customers in selecting an international medical tourism destination.

\subsection{Cultural orientation}

Culture is extensively accepted as the interactive aggregate of the common attributes that affect a group's response to its surroundings (Hofstede, 1980, 1993). It has been traditionally and widely used by cross-cultural management researchers to estimate customers' attitudes and behaviors in various fields of international marketing (e.g., You et al., 2000).

According to the empirical comparison study of Tse et al. (1988), culture has positive influence on the executive's decision making between the China and Canada. Similarly, in order to compare the different behavior of American and Chinese customers in Southern California, Ackerman and Tellis (2001) did a study and found that customers from these two different countries have significantly different buying customs. Chan and Lau (2002) explained green 
purchasing behavior through a cross-cultural study of American and Chinese consumers. Park and Jun (2003) also provided evidences to compare the Internet shopping behavior differences between Republic of South Korea and the United States of American. The research in different areas of cross-cultural management contributes to the academic document of international medical tourism, when it is experienced a dramatical development as well as increased research.

Indeed, You et al. (2000) have constructed their samples from the United Kingdom and Japan to investigate the impact differences of travel push and pull factors. Dong and Liu (2010) carried out meta analysis and suggested a necessary of cross-cultural management in China. Cramer (2018) supported their opinions. With an empirical study, Zhang et al. (2013) explained cultural effect on Chinese customers' destination choice for medical tourism and advocated that more scholars should adopt a cross-cultural perspective. Moreover, Yu and Ko (2012) did a cross-cultural study of perceptions of medical tourism among Chinese, Japanese and Korean tourists in Korea. However, these studies are too limited to understand the whole cross-culture effects. It is because countries such as Europe and China, may have regional cultural differences (Fan, 2000). This opinion is supported by scholars such as Clifton (2011) and Macnab et al. (2010). They investigated the predicable influence of regional culture on customers' behavior through an empirical study, but their studies are concerned with regional comparison in the Western culture. Until now, there is no research to be conducted to study the regional cultural differences in China (Dong \& Liu, 2010), although China's long historical and cultural traditions in different regions have an important effect on the consumption patterns of its people (Qian et al., 2007). David, Lee, Vertinsky, and Wehrung (1988) did insist that it is possible to find distinctions among societies having the same ethnic but different national cultures, such as those in the mainland China and Hong Kong. However, it is not enough for us to understand the regional cultural impact on the customers from different administrative districts. Thus, this research proposes that regional culture affects customers' destination preference significantly.

\subsection{Destination attributes}

Along with the effects of regional culture, the customers' decision of medical tourism may be different depending on the destination features, which include the combined dimensions of medicine and tourism (Zhang \& Lee, 2015).

The current research in the medical tourism literature, has emphasized the importance of medical quality and out-of-pock cost in conjunction with medical reputation in destination choice process (e.g., Connell, 2013; Lunt \& Carrera, 2010; Turner, 2010). Medical quality is generally defined as the customers' evaluation about the facility's whole excellence (Guiry, Scott, \& Vequist, 2011; Rad, Som, \& Zainuddin, 2010), which is consist with the model of SERVQUAL cited by Parasuraman, Zeithaml, and Berry (1985). Scholars such as Zhang et al. (2013) have confirmed the significant impact of medical quality on facility choice. However, higher quality usually indicates that the product or the service is expensive or luxury. As for the customers with higher price elasticity, medical cost is the specifical and the core determinant (Connell, 2013). On the other side, higher quality with a long-time development may become the understructure of the good reputation. As a result, reputation of the medical delivery has a great powerful direction of customers' behavior (Guiry \& Vequist, 2015). The better the reputation is, the more likely the customers are to select the destination.

When travelers seek destinations for medical care, they also desire to have a body relax. Thus, Heung, Kucukusta, and Song (2010) suggest that tourists' decisions vary according to elements of tourism. In general, according to the literature review by Zhang and Lee (2015), the main characteristics of tourism are categorized as attractions, transportation facilities, travel cost, accessibility, and social environment. Attractions include factors such as the weather, the natural beauty, and the cultural attractions in the host country (You et al., 2000). It is the first key determinant of customers' choice decision. If there are no attractions, tourism is meaningless ( $\mathrm{Yu} \& \mathrm{Ko}, 2012$ ). Transportation facilities such as the airports or the subways are becoming more and more important recently, because they are positively related to the cost of traveling (Ritchie \& Crouch, 2000). Travel cost herein indicates the spendings of food, hotel, vehicle, and shopping, excluding the medical cost. According to travel cost, accessibility to the destination also affects customers' decision (Yu \& Ko, 2012). Generally, when the destination or information can be easily accessible, the customers prefer the destination. Social environment means the political stability and society safety. Tourists usually prefer traveling in the host country with a good environment. Overall, with an empirical study, $\mathrm{Yu}$ et al. (2011) concluded that the destination within these attractive features to satisfy the demands of customers, will compete on the generating markets successfully.

\section{Research Model}

According to the literature review, the research model is constructed to estimate the relationships among regional cultures, destination attributes, and preference of medical tourism destination. As addressed in <Figure 1>, regional culture may play an important moderating role between the relations of destination attributes and preference (e.g., Clifton, 2011; Fan, 2000; Macnab et al., 2010; Qian et al., 2007). The different regions in China such as the North, the Northeast, the East, the Central and South, and other 
districts (e.g., the Southwest and the Northwest) are considered in this study. Additionally, in terms of the previous research (e.g., Connell, 2013; Turner, 2010; Zhang \& Lee, 2015; Zhang et al., 2013), destination attributes reflect on medical quality, cost of care, medical reputation, tourism attractions, facilities, travel cost, accessibility, and social environment.

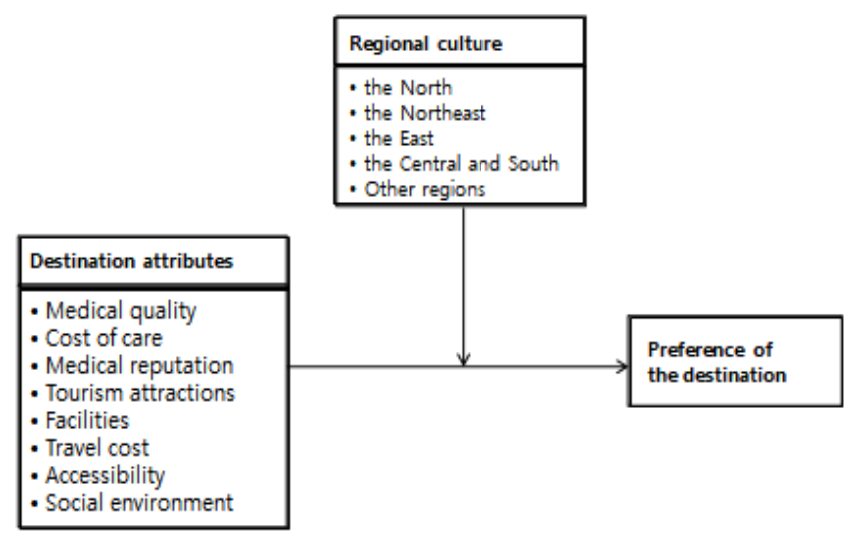

$<$ Figure 1> Research model

\section{Methodology}

\subsection{Data collection}

All the instrument items were adapted from previous research, with some revisions to fit the context of this study. Subsequently, the original questionnaire, using Likert five point scales, was drafted in English and then was translated into Chinese by the native professional researcher respectively. The questionnaire was distributed to thirty Chinese graduate students studied in Korea for a pre-test. Reflecting the findings, the questionnaire was revised.

By distributing the finial questionnaire, residents in different regions of China were surveyed. Generally, there are six regions in China, the North, the Northeast, the East, the Central and South, the Southwest, and the Northwest. The North includes cities or provinces of Beijing, Tianjin, Hebei, Shanxi, and Inner Mongolia, while there are Liaoning, Jilin, and Heilongjiang in the Northeast. The more economically developed provinces and cities of Shanghai, Jiangsu, Zhejiang, Anhui, Fujian, Jiangxi, and Shandong are in the East China. The South Central China includes Henan, Hubei, Hunan, Guangdong, Guangxi, and Hainan. Chongqing, Sichuan, Guizhou, Yunnan, and Tibet are in the Southwest, when Shaanxi, Gansu, Qinghai, Ningxia, Xinjiang are in the Northwest (Wikipedia, 2018). In total, the 2,500 survey questionnaires were distributed to potential customers in these regions. Excluding those with lower reliability, 2,041 surveys $(81.64 \%)$ are used to test regional culture effects.

\subsection{Measurement}

Preference of destination is important because it is the basic step to understand customers' choice (Bass \& Talarzyk, 1972). This study documented the measures of preference from the literature (Chen \& Chang, 2008; Jamal \& Goode, 2001), and modified the items to fit the objective of this article. Additionally, according to the study of Zhang et al. (2013), medical characteristics were constructed by nine items (five items for medical quality, a single item for cost of care, and three items for medical reputation). Elements of tourism were measured characteristics by eighteen items based on the work of Zhang and Lee (2015).

\section{Results}

\subsection{Frequency analysis}

As described in <Table 1>, among the 2,041 residents, there are 395 (19.4\%) respondents from the North, 235 (11.5\%) from the Northeast, 680 (33.3\%) from the East, 467 (22.9\%) from the South Central China, and 264 (12.9\%) from other regions (e.g., the Southwest and the Northwest). The number of females are $822(40.3 \%)$ and 1,219 (59.7\%) males. Most of the respondents are in their twenties (56.0\%) as compare to those in their thirties $(30.0 \%)$. More than half of them have the higher education background $(58.3 \%)$ while 640 with the Master or Ph.D. degree (31.4\%). According to the distribution of average monthly income (exchange rate: 1:6.3): less than US\$316.999 (24.3\%), US\$317 US $\$ 793.999$ (31.4\%), US\$794 - US\$1,269.999 (27.1\%), US $\$ 1,270$ - US $\$ 1,586.999$ (9.9\%), and more than US $\$ 1,587$ (7.3\%), the residents have the abilities to go abroad.

<Table 1> Demographic characteristics of respondents

\begin{tabular}{|c|c|c|c|}
\hline \multicolumn{2}{|r|}{ Items } & Frequency & Percentage \\
\hline \multirow{2}{*}{ Gender } & Male & 1,219 & 59.7 \\
\hline & Female & 822 & 40.3 \\
\hline \multirow{5}{*}{ Age groups } & $20-29$ & 1,143 & 56.0 \\
\hline & $30-39$ & 612 & 30.0 \\
\hline & $40-49$ & 202 & 10.0 \\
\hline & $50-59$ & 66 & 3.1 \\
\hline & 60 or older & 18 & 0.9 \\
\hline \multirow{3}{*}{ Education } & High school & 211 & 10.3 \\
\hline & University/Collage & 1,190 & 58.3 \\
\hline & Graduate school & 640 & 31.4 \\
\hline \multirow{5}{*}{$\begin{array}{c}\text { Salary monthly } \\
\text { (exchange rate: } \\
1: 6.3)\end{array}$} & Less than $\$ 316.999$ & 496 & 24.3 \\
\hline & $\$ 317-\$ 793.999$ & 640 & 31.4 \\
\hline & $\$ 794-1,269.999$ & 554 & 27.1 \\
\hline & $\$ 1,270-\$ 1,586.999$ & 202 & 9.9 \\
\hline & More than $\$ 1,587$ & 149 & 7.3 \\
\hline \multirow{5}{*}{ Region } & the North & 395 & 19.4 \\
\hline & the Northeast & 235 & 11.5 \\
\hline & the East & 680 & 33.3 \\
\hline & the Central and South & 467 & 22.9 \\
\hline & Other regions & 264 & 12.9 \\
\hline Total & & 2,041 & 100 \\
\hline
\end{tabular}




\subsection{Factor analysis and reliability analysis}

The exploratory factor analysis was carried out to reduce the dimensions of the items. By principal component analysis with varimax rotation, the Kaiser-Meyer-Olkin (KMO) 0.947 and Bartlett's test of sphericity 28,296.807 ( $p<0.001)$ addressed in $<$ Table $2>$ indicate that the data is appropriate for the factor analysis (Malhotra, 2007).

The eigenvalues, the total variance extracted, and factor loadings are used to determine the number of the derived variables. The eigenvalues greater than 1.0 are considered significant. The value of the total variance extracted $64.104 \%$ implies that it is statistically significant at the level of $60 \%$. Factor loadings over 0.5 indicate the high convergent validity (Hair, Black, Babin, Anderson, \& Tatham, 2006). The values of Cronbach's alpha are exceeded the guidelines of 0.7 , indicating an adequate level of internal consistency of each construct (Nunnally, 1967).

\subsection{Analysis of variance}

Analysis of variance (ANOVA) was used to test the differences of destination preference according to regions. As shown in <Table $3>$, the value of $F$ is 9.128 ( $d f=2,040)$, and the $p$-value is under the guideline of 0.001 , indicating that there are significant preference differences across regions in China.

In order to analysis the detail preference differences among the regions, the post hoc test of Scheffe is selected to confirm the propositions. According to the results, some mean differences are positively significant at the level of 0.05. Firstly, significant differences of preference exist between the North and the Northeast. Moreover, customers' preference in the North is different from those in the East. Additionally, the preference of customers in the Northeast is significantly different from those in the Central and South, while customers from the Central and South have different preference as compared to those from the East. Unfortunately, there are no significant preference differences in the other comparing sets such as the customers in the North and the South Central China.

<Table 2> Exploratory factor analysis and reliability tests

\begin{tabular}{|c|c|c|c|c|}
\hline Variables* & Items & Cronbach's alpha & Eigen values** & Factor loading \\
\hline \multirow{5}{*}{$\begin{array}{c}\text { Medical } \\
\text { quality }\end{array}$} & The up-to-data equipment & \multirow[t]{5}{*}{0.874} & \multirow[t]{5}{*}{6.423} & 0.752 \\
\hline & The convenience facility & & & 0.650 \\
\hline & The general service level & & & 0.685 \\
\hline & The physician diagnosis skill & & & 0.784 \\
\hline & The procedure accuracy and effectiveness & & & 0.787 \\
\hline \multirow{3}{*}{$\begin{array}{l}\text { Medical } \\
\text { reputation }\end{array}$} & The general medical reputation & \multirow[t]{3}{*}{0.806} & \multirow[t]{3}{*}{3.854} & 0.653 \\
\hline & The medical reputation competition & & & 0.677 \\
\hline & The medical reputation in the market & & & 0.666 \\
\hline \multirow[t]{6}{*}{ Attractions } & The weather & \multirow[t]{6}{*}{0.868} & \multirow[t]{6}{*}{2.389} & 0.536 \\
\hline & The natural attractions & & & 0.703 \\
\hline & The cultural attractions & & & 0.781 \\
\hline & The cultural heritage & & & 0.803 \\
\hline & The ethnic groups and cultures & & & 0.785 \\
\hline & The creational attractions & & & 0.625 \\
\hline \multirow[t]{4}{*}{ Facilities } & The transportation convenience & \multirow[t]{4}{*}{0.798} & \multirow[t]{4}{*}{1.314} & 0.627 \\
\hline & The local food and beverage & & & 0.735 \\
\hline & The accommodation convenience & & & 0.704 \\
\hline & The shopping opportunities & & & 0.608 \\
\hline \multirow[t]{3}{*}{ Accessibility } & The accessibility to get the information & \multirow[t]{3}{*}{0.739} & \multirow[t]{3}{*}{1.006} & 0.722 \\
\hline & The accessibility to arrive the destination & & & 0.810 \\
\hline & The geographical location & & & 0.590 \\
\hline \multirow{4}{*}{$\begin{array}{c}\text { Social } \\
\text { environment }\end{array}$} & The local people & \multirow[t]{4}{*}{0.845} & \multirow[t]{4}{*}{1.854} & 0.717 \\
\hline & The traveling safety & & & 0.750 \\
\hline & The socially and politically stable & & & 0.742 \\
\hline & The openness and passion & & & 0.725 \\
\hline \multirow[t]{3}{*}{ Preference } & The preference of the destination & \multirow[t]{3}{*}{0.803} & \multirow[t]{3}{*}{1.111} & 0.772 \\
\hline & Better than others & & & 0.771 \\
\hline & The intention to visit the destination & & & 0.785 \\
\hline
\end{tabular}

* KMO: 0.947; Bartlett's Test of Sphericity: 28,296.807 ( $p$ < 0.001); Total variance extracted: $64.104 \%$.

** Extraction Method: Principle Component Analysis. 
$<$ Table 3> ANOVA results

\begin{tabular}{|c|c|c|c|}
\hline Scheff & & eference & \\
\hline Region & $\begin{array}{c}\text { Mean } \\
\text { differences }\end{array}$ & \begin{tabular}{|c|}
$F$ \\
(df)
\end{tabular} & p-value \\
\hline the North vs. the Northeast & $-0.337^{\star \star \star}$ & \multirow{10}{*}{$\begin{array}{c}9.128 \\
(2,040)\end{array}$} & \multirow{10}{*}{$0.000^{\star * \star}$} \\
\hline the North vs. the East & $-0.217^{\star \star}$ & & \\
\hline the North vs. the Central and South & -0.069 & & \\
\hline the North vs. others & -0.176 & & \\
\hline the Northeast vs. the East & 0.120 & & \\
\hline the Northeast vs. the Central and South & $0.268^{* *}$ & & \\
\hline the Northeast vs. others & 0.161 & & \\
\hline the East vs. the Central and South & $0.148 \dagger$ & & \\
\hline the East vs. others & 0.041 & & \\
\hline the Central and South vs. others & -0.107 & & \\
\hline
\end{tabular}

\subsection{Regional culture effect}

Regression analysis was used to estimate the regional culture effect on Chinese customers' preference. The findings are addressed in <Table 4>. Model 1 describes the influence of destination attributes on destination preference when the regional culture is not considered. According to the values of $R^{2}(0.326)$ and $X^{2}$ (123.050, $p<0.05)$, there is a good fitness of this regression model.

Medical quality, cost of care, medical reputation, attractions, accessibility, and social environment have the positive predictions of destination preference. Coefficients are the good indexes to explain the effects of destination attributes on preference. For example, medical quality affects destination preference under the guideline of 0.001 . The coefficient value is 0.131 , which indicates that when the perception of medical quality increase 1 unit, the preference of the customer to select the country for medical tourism will raise 0.131 unit.

Moreover, in order to test the moderating role of regional culture, data is selected according to different districts. Model 2 distinguishes the results of the North, while Model 3 is about the Northeast. Model 4 summaries the results of the East, and Model 5 is about the Central and South. Model 6 presents the findings from other regions in China. All the values of $X^{2}$ are significant at the level of 0.05 , thus indicating a good fitness.

$<$ Table 4> Regional culture effects

\begin{tabular}{|c|c|c|c|c|c|c|}
\hline Variable & Model 1 & $\begin{array}{c}\text { Model } 2 \\
\text { (the North) }\end{array}$ & $\begin{array}{c}\text { Model } 3 \\
\text { (the Northeast) }\end{array}$ & $\begin{array}{c}\text { Model } 4 \\
\text { (the East) }\end{array}$ & $\begin{array}{l}\text { Model } 5 \\
\text { (the Central and } \\
\text { South) }\end{array}$ & $\begin{array}{l}\text { Model } 6 \\
\text { (Others) }\end{array}$ \\
\hline & $\begin{array}{l}\text { Coefficient } \\
\text { (Beta) }\end{array}$ & $\begin{array}{l}\text { Coefficient } \\
\text { (Beta) }\end{array}$ & $\begin{array}{l}\text { Coefficient } \\
\text { (Beta) }\end{array}$ & $\begin{array}{l}\text { Coefficient } \\
\text { (Beta) }\end{array}$ & $\begin{array}{l}\text { Coefficient } \\
\text { (Beta) }\end{array}$ & $\begin{array}{c}\text { Coefficient } \\
\text { (Beta) }\end{array}$ \\
\hline Constant & 0.445 & 0.213 & 0.135 & 0.610 & 0.541 & 0.183 \\
\hline Medical quality & $\begin{array}{c}0.131^{* * *} \\
(0.112)\end{array}$ & $\begin{array}{l}0.193^{*} \\
(0.147)\end{array}$ & $\begin{array}{l}-0.130 \\
(0.111)\end{array}$ & $\begin{array}{l}0.142^{*} \\
(0.116)\end{array}$ & $\begin{array}{l}0.140^{*} \\
(0.132)\end{array}$ & $\begin{array}{c}0.086 \\
(0.083)\end{array}$ \\
\hline Cost of care & $\begin{array}{l}-0.038^{\dagger} \\
(-0.040)\end{array}$ & $\begin{array}{c}-0.052 \\
(-0.050)\end{array}$ & $\begin{array}{l}0.066 \\
(0.064)\end{array}$ & $\begin{array}{l}-0.087^{*} \\
(-0.087)\end{array}$ & $\begin{array}{c}-0.035 \\
(-0.044)\end{array}$ & $\begin{array}{l}-0.044 \\
(-0.051)\end{array}$ \\
\hline $\begin{array}{l}\text { Medical } \\
\text { reputation }\end{array}$ & $\begin{array}{c}0.165^{\star \star *} \\
(0.145)\end{array}$ & $\begin{array}{l}0.208^{* *} \\
(0.164)\end{array}$ & $\begin{array}{c}0.411^{* * *} \\
(0.363)\end{array}$ & $\begin{array}{l}0.169^{* *} \\
(0.142)\end{array}$ & $\begin{array}{c}0.057 \\
(0.054)\end{array}$ & $\begin{array}{l}0.204^{* *} \\
(0.203)\end{array}$ \\
\hline Attractions & $\begin{array}{c}0.127^{\star * *} \\
(0.112)\end{array}$ & $\begin{array}{c}-0.047 \\
(-0.040)\end{array}$ & $\begin{array}{c}0.072 \\
(0.065)\end{array}$ & $\begin{array}{c}0.246^{* * *} \\
(0.216)\end{array}$ & $\begin{array}{l}0.099 \dagger \\
(0.086)\end{array}$ & $\begin{array}{l}0.193^{\star \star} \\
(0.181)\end{array}$ \\
\hline Facilities & $\begin{array}{c}0.023 \\
(0.019)\end{array}$ & $\begin{array}{c}-0.062 \\
(-0.048)\end{array}$ & $\begin{array}{c}-0.033 \\
(-0.029)\end{array}$ & $\begin{array}{c}0.008 \\
(0.007)\end{array}$ & $\begin{array}{c}0.022 \\
(0.019)\end{array}$ & $\begin{array}{l}0.255^{\star *} \\
(0.250)\end{array}$ \\
\hline Travel cost & $\begin{array}{l}-0.003 \\
(-0.003)\end{array}$ & $\begin{array}{c}0.077 \\
(0.073)\end{array}$ & $\begin{array}{c}0.025 \\
(0.026)\end{array}$ & $\begin{array}{c}0.023 \\
(0.024)\end{array}$ & $\begin{array}{l}-0.043 \\
(-0.052)\end{array}$ & $\begin{array}{l}-0.059 \\
(-0.073)\end{array}$ \\
\hline Accessibility & $\begin{array}{l}0.162^{* * *} \\
(0.155)\end{array}$ & $\begin{array}{l}0.216^{\star * *} \\
(0.194)\end{array}$ & $\begin{array}{l}0.227^{* *} \\
(0.213)\end{array}$ & $\begin{array}{l}0.156^{\star * *} \\
(0.147)\end{array}$ & $\begin{array}{l}0.184^{* * *} \\
(0.177)\end{array}$ & $\begin{array}{c}0.037 \\
(0.042)\end{array}$ \\
\hline $\begin{array}{c}\text { Social } \\
\text { environment }\end{array}$ & $\begin{array}{c}0.252^{* * *} \\
(0.225)\end{array}$ & $\begin{array}{c}0.296^{* * *} \\
(0.224)\end{array}$ & $\begin{array}{c}0.278^{* * *} \\
(0.258)\end{array}$ & $\begin{array}{l}0.126^{* *} \\
(0.114)\end{array}$ & $\begin{array}{c}0.392^{* * *} \\
(0.354)\end{array}$ & $\begin{array}{c}0.223^{* * *} \\
(0.233)\end{array}$ \\
\hline $\mathrm{N}$ & 2,041 & 395 & 235 & 680 & 467 & 264 \\
\hline $\mathrm{R}^{2}$ & 0.326 & 0.241 & 0.478 & 0.284 & 0.374 & 0.576 \\
\hline$x^{2}$ & 123.050 & 15.319 & 25.849 & 33.230 & 34.247 & 43.255 \\
\hline$p$-value & $0.000^{\star * *}$ & $0.000^{\star * *}$ & $0.000^{* * *}$ & $0.000^{\star * *}$ & $0.000^{\star * *}$ & $0.000^{\star * *}$ \\
\hline
\end{tabular}

$+p<0.1 ;{ }^{*} p<0.05 ;{ }^{* *} p<0.01 ;{ }^{* * *} p<0.001$ 
Obviously, regional culture works as an important moderator when making a decision for medical tourism according to the coefficients and the absolute values of standard coefficients, beta. For example, customers from the North, the East, and the South Central China care medical quality, but customers from other regions not. Especially, as compared to the absolute values of the standard coefficients in the three regions, the medical quality has the most influence on the preference of Chinese customers from the North. The influence of the medical quality on preference related to the customers from the Central and South are ranked in the second level, following by those from the East. Therefore, destinations providing higher medical quality can attract more customers from the regions of the North, the East, and South Central China. What is more important, it is the most effective method to attract the Chinese customers from the North through improving the medical quality. Only customers in the economic area of the East take medical cost as the important alternative. The more the economy of the region develops, the more the customers care medical cost. Residents in the Central and South do not rely on medical reputation to make a decision. It is because customers in this region rely on medical quality to make a decision. However, in Model 2, Model 3, Model 4, and Model 6, medical reputation matters. Furthermore, the influences of medical reputation on preference can be compared by the absolute values of the standard coefficients. As a result, different effects of medical reputation on preference exist among these regions. Attractions have significant effects on preference of customers from the East, the South Central China, and other regions, indicating that attractive traveling products are important for these customers. And the impacts of attractions on customers' preference are different as compared to the absolute values of the standard coefficients.

However, attractions have no influence on the customers in the North and the Northeast. It may be because that the major objectives of the customers in both regions are usually travelling for disease treatment, not tourism. Accessibility has significant influence on preference of medical tourism in the regions of the North, the Northeast, the East, and the South Central China, and the influences are difference, but not in the other districts. For most of the Chinese customers, the destination, closed to China or easy to get the information, is attractive. Interestingly, facilities are the important predictors of preference in Model 6, but not in the regions of the North, the Northest, the East, and the South Central China. Therefore, destinations far from China, may improve traveling facilities to attract Chinese customers from the other regions. Moreover, social environment is the important predictor of medical tourism preference in all the Chinese regions. Chinese customers in each region prefer the country with safe and stable environment. More importantly, the Chinese customers consider social environment as the most critical factor when making a decision. Unfortunately, travel cost does not matter in all regions. Chinese customers do not care travel cost when they have decided to go abroad for medical tourism.

\section{Conclusion}

\subsection{Review of the findings}

This study was undertaken to understand the culture effect on Chinese customers' preference in selecting international destination for medical tourism. As China is the country with various cultures, it is proposed that customers' preference is widely different in accordance with different regional culture. The author collected data from all over China, and made an interesting conclusion under the research findings.

The results of this study make it clear that the regional culture has an interaction impact in the China market of medical tourism, which is supported for the previous proposition by Fan (2000). Given the different cultural background in China, the impact of some destination attributes on customers' choice decision is different. For example, medical quality has significant influence on the customers' preference in the North, but not in the Northest. Therefore, there are different preferences between customers in both regions. Moreover, preference differences exist between the regions of the North and the East. It may be because cost of care and attractions are the important predictors for the customers in the East, but not in the North. As compared to customers in the Northeast, preference of customers in the Central and South is different. As the medical quality and attractions affect customers' preference in the Central and South, but both factors have no impact on preference of customers in the Northeast. Cost of care and medical reputation have significant effects on preferences of customers in the East, but not in the Central and South. Therefore, significant differences of preferences exist between both regions. These findings are consist with the literature cited by Connell (2013) and Qian et al. (2007).

\subsection{Implications}

In terms of the results, it can be concluded that regional culture is important moderator in the relations between destination attributes and preference. The destination, hoping to increase the market share or to be the hub of medical tourism in China, should make strategies in response to regional cultural differences. In other words, practitioners can use regional culture as the descriptive variable to segment the market of China, and then the different strategy should be made as reflecting the specific characteristics in different cultural groups. 
Secondly, within the effect of regional culture, destination characteristics have different effects on Chinese travelers' motives and benefit-seeking behaviors. From a marketing perspective, the strategies may differ for attracting more customers from different cultural orientation. For instance, understanding the role of medical quality in the choice decision process to seek medical destination over borders, it is important for marketers to pay attention to improve the service quality of the medical facilities. Especially, medical quality has more attractive for Chinese customers in the regions of the North, the East, and the South Central China. Hospitals therefore in these host countries should make efforts to provide the most up-to-data equipments or engage doctors to enhance their professional technology for treatment. Ideally, an educational systems for nurses and the general employers' training are necessary. It is because the better the attitudes of the nurses and the employers in the host country, the higher the selection probability of the medical delivery is for the customers in these Chinese regions.

The method of improving medical quality is the most effective strategy for the North to attract the Chinese clients as compared to the East and the South Central China. Unfortunately, customers sometimes have various restrictions to evaluate the quality of the destination's medical facility, because they are lack of knowledge and international experiences. In the situation of this case, medical reputation is the best tool for marketing, and it is the most effective marketing method in the Northeast, followed by the North, the East, and the others.

Thus, managers should first consider raising quality and make sure it can equate to the international certification level. Then they can advertise the reputation through different media. Usually, word-of-mouth is the best channel to be considered for marketing. As another method for attracting the Chinese customers from the East and the South Central China, the package service constructed by medical treatment and tourism should be progressed. More interesting, for the customers in the East, lower medical cost is also an effective method.

\subsection{Limitations and future research}

This study contributes to understand the regional culture effect on the Chinese market, but it has some limitations inevitably. Firstly, regional culture was divided according to the Chinese administrative areas, while China is the great country with 56 various nationalities. Thus the findings of the research are difficult to be generalized. Future study is required to be conducted with data from different nationalities respectively, including national minority. In addition, there are different cities and provinces in each administrative district. In fact, in each city or province, specific culture exists that may influence customers' customs, norms, and beliefs, and in tun affect their decisions. These differences should be considered in the future study, which may contribute to understand the whole impact of cross-culture in China market.

Secondly, this article concerns the main selective attributes to explain customers' choice behavior. The technology develops rapidly as well as the customers' knowledge increases. As a result, service in response to their personalities is more attractive for customers. This requires future research consider wider factors to explain the impact of regional culture on customers when selecting a medical care service overseas, which may be helpful for the development of medical tourism industry.

\section{References}

Ackerman, D., \& Tellis, G. (2001). Can culture affect prices? A cross-cultural study of shopping and retail prices. Journal of Retailing, 77, 57-82.

Bass, F. M., \& Talarzyk, W. W. (1972). An attitude model for the study of brand preference. Journal of Marketing Research, 9, 93-96.

Bird, A., \& Mendenhall, M. E. (2016). From cross-cultural management to global leadership: Evolution and adaptation. Journal of World Business, 51, 115-126.

Chan, R. Y. K., \& Lau, L. B. Y. (2002). Explaining green purchasing behavior: A cross-cultural study on American and Chinese consumers. Journal of International Consumer Marketing, 14(2/3), 9-40.

Chen, C-F., \& Chang, Y-Y. (2008). Airline brand equity, brand preference, and purchase intentions: The moderating effects of switching costs. Journal of Air Transport Management, 14, 40-42.

China Business Industry Research Institute of ASKCl. (2016). A study of Chinese medical tourism in 2016. Retrieved May 25, 2016 from http://www.askci.com/news/hlw/20160525/1750332072 7.shtml.

China Tourism Academy. (2017). Annual report of China outbound tourism development 2017. Tourism Education Press.

Cramer, T. (2018). Cross-cultural management in China. East Asian Journal of Business Management, 8(1), 17-22.

Cllifton, N. (2011). Regional culture in the market place: Place branding and product branding as cultural exchange. European Planning Studies, 19(11), 1973-1994.

Connell, J. (2013). Contemporary medical tourism: Conceptualization, culture and commodification. Tourism Management, 34, 1-13.

David, K. T., Lee, K., Vertinsky, I., \& Wehrung, D. A. (1988). Does culture matter? A cross-cultural study of executives' choice, decisiveness, and risk 
adjustment in international marketing. Journal of Marketing, 52, 81-95.

de Mooij, M., \& Hofstede, G. (2011) Cross-cultural consumer behavior: A review of research findings. Journal of International Consumer Marketing, 23, 181-192.

Dong, K., \& Liu, Y. (2010). Cross-cultural management in China. Cross Cultural Management: An International Journal, 17(3), 223-243.

Fan, Y. (2000). A classification of Chinese culture. Cross Cultural Management: An International Journal, 7(2), 3-10.

Ge, J. (2012). Regional culture of China. Guizhou Culture and History, 2, 7-11.

Goodrich, J. N., \& Goodrich, G. E. (1987). Health-care tourism: An exploratory study. Tourism Management, 8(3), 217-222.

Guiry, M., Scott, J. J., \& Vequist IV, D. G. (2011). Experienced and potential medical tourists' service quality expectation. International Journal of Health Care Quality Assurance, 26(5), 433-446.

Guiry, M., \& Vequist, D. G., IV. (2015). South Korea's medical tourism destination brand personality and the influence of personal values. Asia Pacific Journal of Tourism Research, 20(5), 563-584.

Hair, J. F., Jr., Black, W. C., Babin, B. J., Anderson, R. E., \& Tatham, R. L. (2006). Multivariate Data Analysis. Upper Saddle River, NJ: Pearson Education.

Heung, V. C. S., Kucukusta, D., \& Song, H. (2010). A conceptual model of medical tourism: Implication for future research. Journal of Travel \& Tourism Marketing, 27(3), 236-251.

Hofstede, G. (1980). Culture Consequences: International Differences in World-Related Value. London, UK: Sage.

Hofstede, G. (1993). Cultural constraints in management theory. Academy of Management Executive, $7(1)$, 81-93.

Jamal, A., \& Goode, M. M. H. (2001). Consumers and brands: A study of the impact of sell-image congruence on brand preference and satisfaction. Marketing Intelligence \& Planing, 19(7), 482-492.

Lee, M., Han, H., \& Lockyer, T. (2012). Medical tourism: Attracting Japanese tourists for medical tourism experience. Journal of Travel \& Tourism Marketing, 29, 69-86.

Lunt, N., \& Carrera, P. (2010). Medical tourism: Assessing the evidence on treatment abroad. Maturitas, 66, 27-32.

Macnab, B., Worthley, R., \& Jenner, S. (2010). Regional cultural differences and ethical perspectives within the United States: Avoiding pseudo-emic ethics research. Business and Society Review, 115(1), 27-55.
Malhotra, N. K. (2007). Marketing Research: An Applied Orientation (5th ed.). Upper Saddle River: Pearson Prentice Hall.

Nunnally, J. C. (1967). Psychometric theory. New York: McGraw-Hill. In Gilbert A. Churchill, Jr. (1979). A paradigm for developing better measures of marketing constructs. Journal of Marketing Research, XVI, 64-73.

Parasuraman, A., Zeithaml, V. A., \& Berry, L. L. (1985). A conceptual model of service quality and its implications for future research. Journal of Marketing, 4, 41-50.

Park, C., \& Jun, J-K. (2003). A cross-cultural comparison of Internet buying behavior: Effects of Internet usage, perceived risks, and informativeness. International Marketing Review, 20(5), 534-553.

Qian, W., Razzaque, M. A., \& \& Keng, K. A. (2007). Chinese cultural values and gift-giving behavior. Journal of Consumer Marketing, 24(4), 214-228.

Rad, N. F., Som, A. P. M., \& Zainuddin, Y. (2010). Service quality and patients' satisfaction in medical tourism. World Applied Sciences Journal, 10, 24-30.

Ritchie, J. R. B., \& Crouch, G. I. (2000). The competitive destination: A substantiality perspective. Tourism Management, 21(2), 1-7.

Tse, D. K., Lee, K., Vertinsky, I., \& Wehrung, D. A. (1988). Does culture matter? A cross-cultural study of executives' choice, decisiveness, and risk adjustment in international marketing. Journal of Marketing, 52, 81-95.

Turner, L. (2010). Quality in health care and globalization of health services: Accreditation and regulatory oversight of medical tourism companies. International Journal for Quality in Health Care. 23(1), 1-7.

Wikipedia. (2018). List of regions of the People's Republic of China. Retrieved January 24, 2018 from https://en.wikipedia.org/wiki/List_of_regions_of_the_Pe ople\%27s_Republic_of_China.

Wu, C., \& Liang, Q. (2017). Chinese travelers made 261 billion last year. Retrieved July 12, 2017 from http://www.china.com.cn/travel/txt/2017-07/12/content_ 41198732.htm.

You, X., O'Leary, J., \& Hong, G-S. (2000). A crosscultural comparison of travel push and pull factors: United Kingdom vs. Japan. International Journal of Hospitality \& Tourism Administration, 1(2), 1-26.

Yu, J. Y., \& Ko, T. G. (2012). A cross-cultural study of perceptions of medical tourism among Chinese, Japanese and Korean tourists in Korea. Tourism Management, 33, 80-88.

Yu, J., Lee, T. J., \& Noh, H. (2011). Characteristics of a medical tourism industry: The case of South Korea. Journal of Travel \& Tourism Marketing, 28(8), 856-872. 
Zhang, J., \& Lee, H. (2015). Factors influencing Chinese customers' selection of health care service countries: Focusing on word-of-mouth moderating effects. Journal of Distribution Science, 13(12), 41-52.

Zhang, J., \& Lee, H. (2017). The impact of cultural similarity on the international distribution management. Journal of Distribution Science, 15(12), 21-30.
Zhang, J., \& Lee, H-Y. (2018). The cultural similarity effects on the industry of medical tourism. International Journal of Industrial Distribution \& Business, 9(1), 67-76.

Zhang, J., Seo, S., \& Lee, H. (2013). The impact of psychological distance on Chinese customers when selecting an international healthcare service country. Tourism Management, 35, 32-40. 